\title{
The changing role of sociolinguistics and its reflection in ELT
}

\section{Linda Chmelařová, Ondřej Duda}

\begin{abstract}
The paper deals with the question whether and to what extend the Internet, social media and modern trends in human communication impact the language use of students of English. The authors used a qualitative method of focus group in order to gain relevant data. The results of the inquiry include the comments of teachers of English (native speakers) teaching future English teachers at the Faculty of Education, Palacký University Olomouc on features of the English language the students encounter.
\end{abstract}

Key words: sociolinguistics, approach, new media, social sites, the Internet, language, use of language, English language, globalization.

\section{Měnící se role sociolingvistiky a její reflexe v ELT}

\begin{abstract}
Abstrakt
Příspěvek se zabývá otázkou, zda a nakolik ovlivňuje internet, sociální média a moderní trendy v lidské komunikaci používání jazkya u studentů angličtiny. Autoři použili pro sběr relevantních dat kvalitativní metodu focus group. Výsledky šetření zahrnují poznámky učitelů angličtiny (rodilých mluvčích), kteří učí budoucí učitele angličtiny na Pedagogické fakultě Univerzity Palackého v Olomouci, o rysech anglického jazyka, se kterými se studenti setkávají.
\end{abstract}


Klíčová slova: sociolingvistika, přístup, nová média, sociální sítě, internet, jazyk, používání jazyka, anglický jazyk, globalizace.

\section{Introduction}

In recent years a new phenomenon has appeared that has completely changed people's lives, including the way they communicate: the existence of the Internet and social media. The stream of information and cultural intake has become unified as a large number of people in the developed world absorb it from the same source. The question which arises is whether this change has caused, or might cause, a new situation in which all the other factors lose their previous role of forming the language people use and labelling those people according to their language features. In this article the authors attempt to add a new perspective that considers modern trends in human communication that should be researched by modern sociolinguistics. In tertiary education in the Czech Republic the Internet and its impact on language use are worth analyzing, most importantly when future English teachers are taken into consideration. For that reason, the practical part of the article includes comments of teachers of English (native speakers) teaching future English teachers at the Faculty of Education, Palacký University in Olomouc on features of the English language the students encounter in course books and also the features they adopt from reading and watching various content on the Internet.

\section{Sociolinguistics and globalization}

As a result of globalization distances have shortened and possibilities have grown, which has influenced all fields of human activity, including sociolinguistics, because of the dissemination of language to all parts of the world through media. For example, Blommaert, writing in 2010 at the dawn of smart electronic devices, commented that 'globalization forces sociolinguistics to unthink its classic distinctions and biases and to rethink itself as a sociolinguistics of mobile resources, framed in terms of trans-contextual networks, flows and movements' (Blommaert, 1). Moving human activities onto the international level gives rise to new demands on language competences and at the same time brings new language forms and features as a result of the mixing and mutual influence of languages. The mobility of people involves the mobility of linguistic and sociolinguistic features. 'The possibility of frequent electronic contact with the country of origin, for instance, can generate new forms of language innovation...' (Blommaert, 5). When referring to the virtual world, Blommaert presents the Internet as a wide and virtually uncontrolled space for language learning. Crystal (2006) sees the Internet world as an 
extremely fluid one, in a permanent state of transition, lacking precedent, struggling for standards, and searching for direction. In fact the Internet has replaced television, which brought the first cultural and linguistic explosion on a very limited scale when compared to the Internet, which serves as an 'individualized medium' which reacts to the specific demands of each individual.

\section{The young generation and the Internet}

The generation which is currently most influenced by the Internet (not only from the linguistic point of view) is the generation of teenagers and adolescents. Young people use the Internet for different reasons from the previous generations. The space which was previously devoted to electronic communication through emails and chats has moved to a new dimension of social media sites, such as Facebook, Instagram, YouTube, and sites that store and stream films and TV series. The stream of videos and information is easily accessible and targets especially at the young generation, which is susceptible to acquiring new language forms and variations. In most cases, there is a common shift of language from a neutral, standard form to a more informal one containing many slang and emotionally coloured words. When concentrating on the use of English (as it is undoubtedly the lingua franca of the Internet these days) this virtual shaping of linguistic performance has an influence not only on native speakers but also on students studying English, who use the Internet for both study purposes and personal amusement in their leisure time. As the interest of these students has moved from absorbing standard and neutral English from coursebooks and literature (which were the only sources in the past) to popular sitcoms, TV series, and YouTube videos, it is probable that their language use will be different, especially when the level of formality and choice of vocabulary are taken into consideration. Regarding this process, it will be even more difficult to state what an accepted language form looks like and where the borders of correctness and incorrectness lie, especially in the case of speech.

\section{Traditional approach versus new approach}

The language we use is strongly influenced by many factors which shape the choice of language forms on all levels, from phonetic variations through the use of vocabulary to syntactic structures and appropriate (situationally determined) style. Language represents a fundamental factor which can reveal a lot about the environment we come from. The field which studies the relation between language and society is called sociolinguistics. 'It's a field of study that assumes that human society is made up of many related patterns and behaviours, some of which are linguistic.' (Spolsky, 3) While in the 
past the social and geographical aspects used to be quite stable, which means people lived in a restricted environment in the group of their social community, thanks to the changes in recent decades travelling and information exchange have achieved new levels. Human contacts with unknown cultures, together with their language variations, are much more frequent and intense. Thus, the traditional categorization of sociolinguistics dealing with the factors which influence one's language performance appears to rest on quite an unstable base.

Sociolinguistic development begins in early childhood, when children generalize the linguistic models which they follow. As Hudson (1980) points out, these patterns come first from parents, then peers, and then adults. The peer-oriented stage seems to be strongly influential as it evidently wins over the parents-oriented period. Furthermore, it is obvious that many children of first-generation immigrants develop accents distinguishable from those used by their non-immigrant friends and family members. Hudson also mentions Hockett (1950), who refers to this phenomenon as age-grading. According to this concept, there are some linguistic forms that are used only by children in the peer-oriented stage and can be transmitted from one generation to the other but are not used by adult speakers.

In the past it was believed that the community which surrounded a person was further classified within the society depending on the social class it represented. The work of William Labov in New York established for the first time the term 'social stratification'-the study of class distinction in speech-which later became a major topic in sociolinguistics (Spolsky, 39). Stockwell points out that 'this is not an easy concept to define precisely or measure accurately, and the stratification of class into different levels varies considerably across nations and cultures' (Stockwell, 11). Nevertheless, it is evident that each society or language community has a certain hierarchy of wealth, power, and prestige defined by people's economic and social status. As these people share a similar cultural background and mostly communicate with one another, their mutual influence is indisputable. The feeling of inclusion in a social group might be stronger than geographical factors because'a speaker may show more similarity in his language to people from the same social group in a different area than to people from a different social group in the same area' (Hudson 43). In the case of the United Kingdom "higher-class" people tend to exhibit similar linguistic features as they passed through the system of public schools and do not display regional traits in comparison to lower-class people, who show a greater variety of language, depending on the region they live in. On the other hand, Hudson (1980) emphasizes that this situation is common for the UK but in other countries such as the USA or Germany "top people" show more of their region of origin through language. Nowadays, many borders among countries in the developed world exist only formally, and today's means of transport and 'virtual travelling' are achievable for people who are then culturally and linguistically enriched by other nations. The same situation is visible in terms of social classes. Even though there are 
still obvious social differences within society, human intellectual interests and activities have moved to the virtual world of the Internet, which is available to people regardless of their social class. Moreover, in contemporary society social class is no longer a fixed state imposed by external circumstances, as people tend to choose a status represented by their lifestyle, clothes, attitudes, language, etc.

The other factors which traditionally played a role in the varieties of the language used for communication are age and gender. As mentioned above, some life stages are more important than others for adjusting the choice of language features to the language used by the people around oneself. Moreover, the peer-oriented stage, which also involves the period of puberty, has quite specific traits determined by closer socializing with peers and the struggle to achieve a better position in the social group. Holmes (2008) mentions the heightened use of vulgar expressions and slang, which are typical of this period but later, in adulthood, diminish. Either the expressions sound odd when uttered by older people or social conditions such as having children and meeting other young families make the use of "inappropriate" language undesirable. Considering the aspect of age, it still seems to play an important role in the use of linguistic variations, as people of the same age tend to search for information of a similar character and choose similar sources across borders and countries. As in the past, for instance, teenagers are "uniformed" by their language use and differentiated from the other age groups, no matter where they live.

In terms of gender 'the differences between the way males and females speak were long restricted to grammatical features, such as the differences between masculine and feminine morphology in many languages' (Spolsky 36). Later, more attention was paid to distinctive female and male language varieties. Stockwell (2002) refers to Trudgill, who explains that men aim to achieve more streetwise "macho" standards, whereas women are more commonly judged by appearance and thus tend to use more prestigious features and hypercorrection. Freeman and McElhinny (2001) extend this idea by referring to Lakoff, who 'argues that a female speaker faces a double bind. If she doesn't speak like a lady, she will be criticized, ostracized, or scolded. If, on the other hand, she does learn to speak like a lady, she will be systematically denied access to power on the ground that she is not capable of holding it,...' (McKay \& Hornberger, 231). The differences can also be seen in the choice of lexical items. It is generally stated that women's talk tends to be associated with the home and domestic activities, whereas men's talk tends to be associated with the world outside and economic activities. Despite these differences, in western socialization, as men and women co-exist more closely on both the personal and professional levels, their roles often merge, which also affects the language they use. 'Not surprisingly in Western urban communities where women's and men's social roles overlap, the speech forms they use also overlap' (Holmes, 160). 


\section{Situational factors influencing language performance}

The use of language is not entirely determined by factors existing independently of the communicative context; the specific social situation plays a big role too. The language used for communication with people in a close relationship is different than the language used on a more professional or formal level. The same can be said about the language used for written and oral communication. This characteristic, commonly called register, is one of the main terms used in sociolinguistics. Hudson (1980) differentiates register referring to'varieties according to use', in contrast with dialects, defined as 'varieties according to user'. It is generally stated that people use more correct and formal forms when talking to people with whom they have a more distant relationship. 'The better you know someone, the more casual and relaxed the speech style you will use to them. People use considerably more standard forms to those they don't know well, and more vernacular forms to their friends' (Holmes, 236). A similar distinction can be seen between written and spoken forms of language. The written form is commonly more standard, with fewer slang expressions and contracted or informal forms. Nevertheless, it is evident that a large amount of communication is losing its formal and standard character, which was more common in the past than now. Formal situations do not place such high demands on linguistically formal performance and especially the young generation might find it difficult to be verbally efficient and formal at the same time.

\section{Research aims and methodology}

The aim of the paper is to consider the Internet, social media and modern trends in human communication and their impact on language use of students of English. For the purposes of gaining relevant data, the authors used a qualitative method of focus group (Miovský, 2006). The results of the inquiry include the comments of teachers of English (native speakers) teaching future English teachers at the Faculty of Education, Palacký University in Olomouc on features of the English language the students encounter in course books and also the features they adopt from reading and watching various content on the Internet. There were five respondents between the ages of 25 to 60, with gained formal education in ELT, at the time of the inquiry teaching English at the Institute of foreign languages, Faculty of Education, Palacký University in Olomouc, to future teachers of English. The theme is quite general, for that reasons, the authors asked each respondent several specific questions. Thus everyone had the change to comment on the questions, provide specific answers and also react to others' opinions. For the purposes of this paper, the participants of the discussion will be referred to as Teachers $1-5$, or T1-T5. 
The participants of the focus group were asked these questions:

1. Do you think that students' language performance is influenced by new media such as the Internet, social sites and others in the areas of writing and speaking and why? Examples?

2. Do you think that students use more formal or informal language in writing and speaking and why? Examples?

3. Do you think that students use slang expressions in writing and speaking and why? Examples?

4. In terms of vocabulary do students use abbreviations or acronyms (typical for social media, e.g. lol, asap, btw, brb, etc.) in writing or speaking and why? Examples?

5. Do you think that students use informal language typical for speaking in writing and why? Examples?

6. Do you think students use more American way of pronunciation than British one and why? Examples?

\section{Results and discussion}

The answers to the questions were categorized according to the nature of the questions, answers, or features they referred to.

Table 1

\begin{tabular}{|c|c|c|}
\hline Question & Category & Answer \\
\hline \multirow[t]{7}{*}{ Social Media and the Internet } & \multirow[t]{4}{*}{ Influence on writing } & Yes \\
\hline & & Yes, to a large extent \\
\hline & & Yes, becoming more informal \\
\hline & & Yes, to a certain extent \\
\hline & \multirow[t]{3}{*}{ Influence on speaking } & Yes, to a certain extent \\
\hline & & Yes \\
\hline & & No, more listening \\
\hline \multirow[t]{7}{*}{ Use of informal language } & \multirow[t]{4}{*}{ Writing } & More formal \\
\hline & & Both formal and informal \\
\hline & & More informal \\
\hline & & Rather informal \\
\hline & \multirow[t]{3}{*}{ Speaking } & Tend towards greater informality \\
\hline & & Frequently informal \\
\hline & & More informal \\
\hline
\end{tabular}




\begin{tabular}{|c|c|c|}
\hline Question & Category & Answer \\
\hline \multirow[t]{5}{*}{ Use of slang expressions } & \multirow[t]{2}{*}{ Writing } & Yes, to a small extent \\
\hline & & Occasionally \\
\hline & \multirow[t]{3}{*}{ Speaking } & Yes \\
\hline & & Definitely yes \\
\hline & & To a large extent \\
\hline \multirow[t]{6}{*}{ Use of abbreviations or acronyms } & \multirow[t]{3}{*}{ Writing } & Minimally \\
\hline & & No, never observed \\
\hline & & No \\
\hline & \multirow[t]{3}{*}{ Speaking } & No, never heard \\
\hline & & I don't think so \\
\hline & & No \\
\hline \multirow{4}{*}{$\begin{array}{l}\text { Use informal language typical of speaking } \\
\text { in writing }\end{array}$} & & Yes, very often \\
\hline & & Occasionally, yes \\
\hline & & Yes, in relation to the overuse of phrasal verbs \\
\hline & & Sometimes without realising it \\
\hline \multirow[t]{5}{*}{ American versus British pronunciation } & \multirow[t]{2}{*}{ More American } & Definitely yes \\
\hline & & Blend of both \\
\hline & \multirow[t]{3}{*}{ More British } & Yes, more than American \\
\hline & & Mix of Czech and British features \\
\hline & & Mix of Czech, American and British features \\
\hline
\end{tabular}

The answers to the first question 'Do you think that students' language performance is influenced by new media such as the Internet, social sites, and others in the areas of writing and speaking, and why? Examples?' varied. The teachers agreed that the influence of media on the language that students use is significant, yet more when writing is being considered. For example, teacher 5 commented on the globalization of English:'I think the diversity of "Englishes" online (where regional dialects, formal and informal English, and grammatically incorrect English are often presented side by side) has certainly influenced students' written language. Blogs and social media (Facebook, Twitter) have perhaps normalized a more colloquial style of written English also.' In terms of speaking, an interesting point was emphasized by Teacher 2, that 'students listen more than they actually speak'.

The second question: 'Do you think that students use more formal or informal language in writing and speaking and why? Examples?' was answered with a variety of responses. It can be concluded that the students at the Institute of Foreign Languages who have been taught by the respondents tend to use more informal language in writing and definitely informal language in speaking. This is, of course, individual, as some tend to be more formal in their writing and informal when speaking. Teacher 2 
suggested that the informality in speaking 'seems to be more related to TV than social media'.

The third question regarded the use of slang expressions: 'Do you think that students use slang expressions in writing and speaking, and why? Examples?' It is clear that slang expressions are more common in the spoken form of English than in the written one. These expressions include, for example, phrasal verbs and idioms. Teacher 2 , however, pointed out that sometimes these might unintentionally be used wrongly. Similarly, the fourth question regarded the use of abbreviations or acronyms: 'In terms of vocabulary, do students use abbreviations or acronyms (typical of social media, e.g. lol, asap, btw, brb, etc.) in writing or speaking and why? Examples?' The results show that the tendency to use abbreviations or acronyms is very low or non-existent. For example, Teacher 4 commented: 'I have seen very little evidence of this. I think one reason may be that they are not used so much in Czech social media, which many of the students I teach are probably more familiar with.'

The answers to the fifth question 'Do you think that students use informal language typical of speaking in writing, and why? Examples?' show that students tend to use more informal language typical of speaking in writing. As noted by Teacher 2,'it can sometimes be unintentional' or, as Teacher 5 said, 'often a conversational style is used in their writing'.

The answers to the sixth and final question 'Do you think students use an American way of pronunciation more than a British one and why? Examples?' suggested that students use a more American-influenced way of pronunciation, sometimes supplemented with British features. Teacher 2 said: 'It depends on the student-but on the whole, I would say that most students have a tendency for using American pronunciation over British. Most often they have a blend of both.' Nevertheless, as pointed out by Teacher 5: 'This is really difficult to determine. However, I would say that a British pronunciation is marginally more common among students'; this is difficult to measure, study, and draw conclusions about, and to do that the authors would need to launch a more extensive inquiry.

To conclude, the authors are aware of the fact that the English language is evolving and ever-changing. This fact was also emphasized by Teacher 3, who generalized that: 'The English language is a 'live' medium and will be subject to continual change; it will continue to evolve'. Therefore, this paper is a starting point for more extensive feature research intended to be conducted by the authors in the near future.

\section{References}

Bell, A., \& Garrett, P. (1998). Approaches to Media Discourse. Oxford, England: Blackwell Publishers. Blommaert, J. (2010). The Sociolinguistics of Globalization. Cambridge, England: Cambridge University Press.

Crystal, D. (2006). Language and the Internet. Cambridge, England: Cambridge University Press. Holmes, J. (2008). An Introduction to Sociolinguistics. Harlow, England: Pearson Education Limited. 
Hudson, R. A. (1980). Sociolinguistics. Cambridge, England: Cambridge University Press.

McKay, L. S., \& Hornberger, N. H. (1996). Sociolinguistics and Language Teaching. Cambridge, England: Cambridge University Press.

Miovský, M. (2006). Kvalitativní prístup a metody v psychologickém výzkumu. Prague, Czech Republic: Grada.

Montgomery, M. (1988). An Introduction to Language and Society. London, England: Routledge. Spolsky, B. (1998). Sociolinguistics. Oxford, England: Oxford University Press.

Stockwell, P. (2002). Sociolinguistics. London, England: Routledge.

\section{Contact:}

Mgr. Linda Chmelařová, Ph.D. \& Mgr. Ondřej Duda

The Institute of Foreign Languages

Faculty of Education, Palacký University Olomouc

Žižkovo náměstí 5, 77140 Olomouc

Czech Republic

E-mails: ondrej.duda@upol.cz, linda.chmelarova@upol.cz

Ondřej Duda is Assistant Professor of the English Language at the Institute of Foreign Languages at the Faculty of Education, Palacký University Olomouc. He teaches sociolinguistics, language practice, language skills, and culture and history courses. In his work, he focuses on developing the professional competences of English teachers. His recent academic interest involves the theme of developing the sociolinguistic competence of future teachers of English. He has actively participated in the ERASMUS+ projects GuLL, LEEN and VOICES. Additionally, he is a doctoral candidate for Education at the Institute of Education and Social Studies at the Faculty of Education, Palacký University Olomouc.

Linda Chmelařová primarily deals with organizing English language courses for non-linguists in the Faculty of Education, i.e. students not majoring in Teaching English as a Foreign Language. Her research focuses on improving future lower secondary teachers' language competencies and the analysis of their language needs. She also teaches Language Practice for primary students. 